\title{
METALDEHYDE TOXICITY: A BRIEF ON THREE DIFFERENT PERSPECTIVES
}

\author{
A.M. Saad ${ }^{1}$, S.W. Ismail ${ }^{1}$ and F.A. Dahalan ${ }^{1}$ \\ ${ }^{1}$ School of Environmental Engineering, Universiti Malaysia Perlis, Kompleks Pengajian Jejawi 3, 02600 Arau, \\ Perlis, Malaysia
}

Date received: 03/09/2017, Date accepted: 25/09/2017

Corresponding author's email: linasaad139@yahoo.com

\begin{abstract}
Extensive use of metaldehyde to combat agriculture pest creates environmental problems. Not limited to targeted pests, it also endangers non-target groups including the environment, humans and animals. Its solubility in water is capable of polluting drinking water sources and increases cost of water treatment. Despite the low level of concentration, metaldehyde is able to bioaccumulate over time and causes dysfunction in certain organs. Thus, this paper gives a brief view on the toxicity level of metaldehyde and the permissible concentration range of this compound for three different groups namely sediments and plants, water and animals.
\end{abstract}

Keywords: Metaldehyde, Water Pollution, Sediment, Water, Environmental Engineering.

\subsection{INTRODUCTION}

This paper is a review on metaldehyde distribution and pollution. Extensive use of metaldehyde to combat agriculture pest creates environmental problems. As highlighted by Pesticides Action Network United Kingdom (PAN UK), as a molluscicide, metaldehyde is applied to eradicate gastropods especially slugs and snails [1]. This compound is widely used especially in cultivation of paddy, vegetables, and fruits. The metaldehyde applied, usually ends up in water sources, causing water pollution. Metaldehyde finds its way to water sources via leaching, run off, spray drift and accidental spill [2].

Studies have found that the concentrations of metaldehyde in river and drinking water increased during wet seasons due to run-off from land where this compound was applied [3]. The occurrence of metaldehyde in the aquatic environment affects aquatic biotas like fish and shrimp. This exposes human to potential health risks such as liver and kidney dysfunction as the fish is consumed as a major source of protein [4]. A good correlation has been shown between rates of application and abundant concentrations of this compound in the water system $[5]$.

More worryingly, continuous use of insecticides (including metaldehyde) have contributed to increase in pest resistance [6]. This causes more toxins with higher doses to be used, a problem faced by both developed and developing countries [7, 8]. For example, there were 500 active pesticide compounds listed officially in South Africa, making it the largest user market in the world [9]. This concern has provoked international and national bodies including World Health Organization (WHO), European Union (EU), United States Environmental Protection Agency 


\section{Journal of Civil Engineering, Science and Technology}

Volume 8, Issue 2, September 2017

(US EPA) and United Kingdom Environmental Agency (UK EA) to set up appropriate ranges for the use of these insecticides [10].

For every four cases of infectious diseases, three of them are water borne [11]. Thus, water treatment is one of the important solutions to this problem. At the same time, pollution control at source is necessary, in order to minimize the cost of treatment. Identification of the types of pesticides and maximum dosage is also helpful in maximizing the efficacy of this treatment. Therefore, this paper gives a brief view on toxicity level of metaldehyde and the permissible concentration range of this compound. It is divided into three different groups, namely sediment and plants, water and animals.

\subsection{CHARACTERISTICS}

Metaldehyde or chemically known as 2, 4, 6, 8 - tetramethyl - 1, 3, 5, 7 - tetraoxacyclooctane is made by polymerization of acetaldehyde. It is prepared by treating acetaldehyde with hydrogen chloride $(\mathrm{HCl})$ at low temperature, as shown in Figure 1. Suitable temperature is important to produce a high yield of metaldehyde [12].

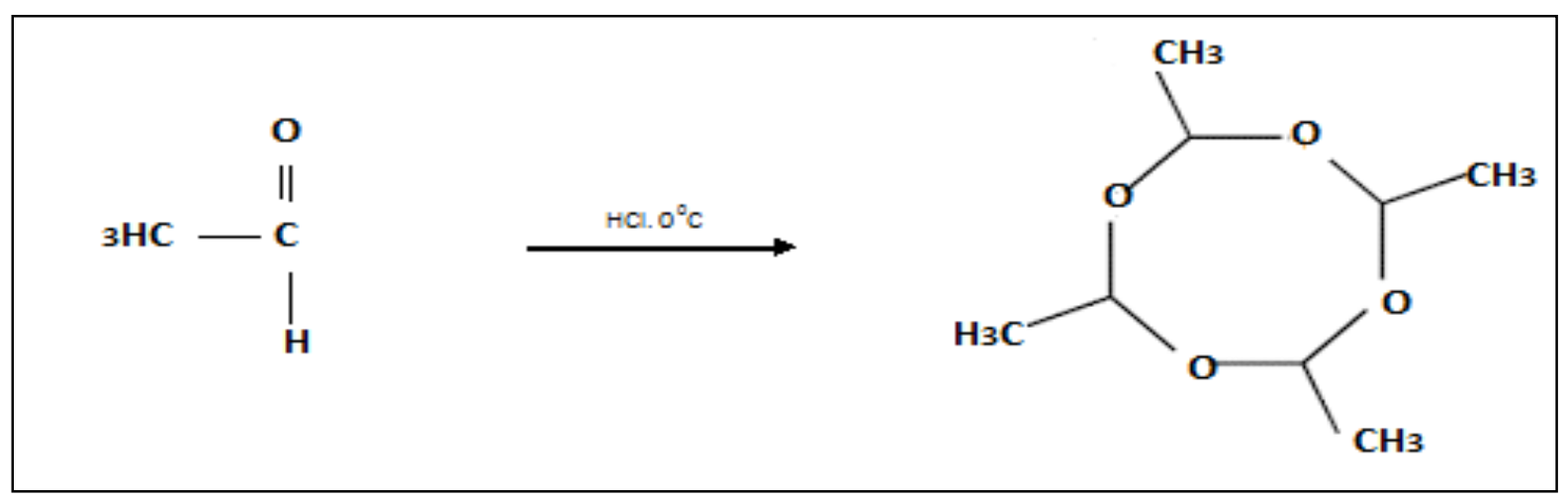

Figure 1 Polymerization of acetaldehyde to metaldehyde

This molluscicide appears as a white or colourless powder or crystalline solid. Metaldehyde solubility in water measures at $20^{\circ} \mathrm{C}$ and $\mathrm{pH}$ at $5,6.5,7.2$, and 9 is $0.2 \mathrm{~g} / \mathrm{L}$ and $\log \mathrm{P}$ of 0.12 [13]. Table 1 displays the physical and chemical properties of metaldehyde as explained in [2, $14]$.

Table 1: Physical and chemical properties of metaldehyde

\begin{tabular}{ll}
\hline Properties & \\
\hline Colour & White/Colorless \\
Molecular formula & $\mathrm{C}_{8} \mathrm{H}_{16} \mathrm{O}_{4}$ \\
Molecular weight $(\mathrm{g} / \mathrm{mol})$ & $176.2 \mathrm{~g} / \mathrm{mol}$ \\
Vapor pressure & $6.6 \pm 0.3 \mathrm{~Pa}$ at $25^{\circ} \mathrm{C} / 4.4 \pm 0.2 \mathrm{~Pa}$ at $20{ }^{\circ} \mathrm{C}$ \\
Melting point & $246{ }^{\circ} \mathrm{C}$ \\
Boiling point & 112 to $115^{\circ} \mathrm{C}$ \\
Solubility in water & Slightly soluble at $200 \mathrm{mg} / \mathrm{L}\left(17^{\circ} \mathrm{C}\right)$ \\
Odor & Mild characteristic odour \\
\hline
\end{tabular}




\section{Journal of Civil Engineering, Science and Technology}

Volume 8, Issue 2, September 2017

\subsection{TOXICITY}

\subsection{METALDEHYDE IN SEDIMENTS AND PLANTS}

Presence of metaldehyde in paddy field sediment can be detected after only three days of use [15]. Concentrations of metaldehyde varied from $0.053 \mathrm{mg} / \mathrm{kg}$ to $0.127 \mathrm{mg} / \mathrm{kg}$, between three days to two weeks after application. Low concentration in the sediment was due to its water soluble characteristics. At the same time, the sediment absorption rate for this compound was lower than water. In another report by [16], $27 \mathrm{mg} / \mathrm{kg}$ to $32 \mathrm{mg} / \mathrm{kg}$ of metaldehyde were detected in sediment during the rainy season. During the dry season, a range of $31 \mathrm{mg} / \mathrm{kg}$ to 42 $\mathrm{mg} / \mathrm{kg}$ were detected in a rice cultivation area. Dilution effect caused by rain may contribute to the differences between seasons.

In contrast, there was a decline in the metaldehyde concentration in the sediment taken from a fish pond [17]. Specifically, a total concentration of $80 \mathrm{mg} / \mathrm{kg}$ was recorded on the first day, followed by $23 \mathrm{mg} / \mathrm{kg}$ on the third day, and only $1 \mathrm{mg} / \mathrm{kg}$ metaldehyde on the fifteenth day. Biodegradation was a factor enabled the reduction of concentration. Biodegradation decomposes complex compounds into simple compounds, following microbial (Pseudomonas sp. and Bacillus sp.) activities [18]. The sediment in the pond was more watery than the sediment in paddy fields. Thus, this pesticide tended to dissolve in water rather than remain in the soil.

Metaldehyde was also detected in harvested fruits and vegetables. However, concentration were low in both items. Only $0.075 \mathrm{mg} / \mathrm{kg}$ was detected in the stalk of rice plant [15]. For cabbage, the residues of metaldehyde were in the range $17.4 \mathrm{mg} / \mathrm{kg}$ to $68.6 \mathrm{mg} / \mathrm{kg}$ for samples collected at three different locations [19]. The same study highlighted that the concentration of metaldehyde in plants was ten times more than in the soil. Although the multiplication rate was high, it was still below the minimum detection level. This once again is explained by its water soluble characteristic that makes this compound a formidable water pollutant.

In monitoring the presence of metaldehyde in foodstuffs, some countries such as the United States and Canada had established maximum residue limits (MRL) of metaldehyde. There are some differences in maximum residue units applied in both countries. The acceptance levels of metaldehyde in the USA for vegetable products such as tomatoes, berries, and cabbage were higher than acceptable levels in Canada. The differences were due to certain reasons such as data collection, sampling sites and application of pesticide. Table 2 shows six types of plant with given maximum residue limits in both countries [20,21].

Table 2: Permitted limit of metaldehyde residue in Canada and USA

\begin{tabular}{lll}
\hline Product & MRL in Canada $(\mathrm{ppm})$ & Acceptance levels in the USA (ppm) \\
\hline Tomatoes & 0.09 & 0.24 \\
Head lettuce & 0.15 & 1.73 (lettuce) \\
Leaf lettuce & 1.50 & 1.73 (lettuce) \\
Cranberries & 0.15 & 0.15 \\
Low growing berries & 0.15 & 6.25 \\
Cabbage & 1.00 & 2.50 \\
\hline
\end{tabular}




\section{Journal of Civil Engineering, Science and Technology}

Volume 8, Issue 2, September 2017

\subsection{METALDEHYDE IN WATER}

Since 2008, the United Kingdom Environmental Agency (UK EA) has stressed the seriousness of metaldehyde pollution in drinking water [22]. However, metaldehyde pollution in the drinking water sources is still on-going. For example, in two years (2009 to 2011) concentrations of metaldehyde were found in almost 85 water reservoirs including rivers, streams, and groundwater [23]. Water pollution in significant amounts caused by metaldehyde has also been reported in other studies $[24,25]$. The contamination of metaldehyde in the water system is believed to originate from agriculture sites. The draining away of this pesticide from the lands of application caused by heavy rain, brings this compound to the water sources.

Metaldehyde contents for both raw water and processed water in the UK were found higher than the permitted level, $(0.1 \mu \mathrm{g} / \mathrm{L})$ [26, 27]. For example, a high value of $1.08 \mu \mathrm{g} / \mathrm{L}$ was detected in Yorkshire River, for the period of 2008-2011. On the other hand, $1.03 \mu \mathrm{g} / \mathrm{L}$ was detected in treated drinking water in November/December 2008 [3]. For other water sources (including rivers and streams), low concentrations of metaldehyde $(0.1 \mu \mathrm{g} / \mathrm{L})$ were detected in the year 2010/2011 [25].

Metaldehyde occurrence is not only limited to the UK. In France, metaldehyde was found at five sampling locations located at the Moselle River. More than half of the samples recorded concentrations in the range of $0.03 \mu \mathrm{g} / \mathrm{L}$ to $6.98 \mu \mathrm{g} / \mathrm{L}$ over the period of 2007-2009 [28]. In Philippines, concentrations of $1.47 \mathrm{mg} / \mathrm{L}$ to $1.58 \mathrm{mg} / \mathrm{L}$ in paddy field water were reported [15]. In another study concentrations of $1.55 \mathrm{mg} / \mathrm{L}$ to $2.35 \mathrm{mg} / \mathrm{L}$ were detected in lake water [17]. Both detections were recorded one to three days after molluscicide was used.

Studies suggest, metaldehyde could be harmful to non-target biota such as human and animals [29]. Metaldehyde enters the bloodstream from the gastrointestinal tract [30]. The level of acute toxicity depends on the amount of intake. In addition, metaldehyde has harmful effects on paddy field and wetland ecosystems. The side effects of metaldehyde were related to reduction or eradication of useful aquatic fauna such as snails [31]. The same study highlighted that the usage of metaldehyde created a new resistant paddy pest which caused rice diseases.

\subsection{METALDEHYDE IN ANIMALS}

Rising incidence of contamination has been found in wild animals and pets [32] caused by ingestion and absorption through skin. In general, metaldehyde is a moderately toxic compound to various animals including dog, rabbit, mice, rats and guinea pigs. The established acute oral $\mathrm{LD}_{50}$ ranged from $100 \mathrm{mg} / \mathrm{kg}$ to $1250 \mathrm{mg} / \mathrm{kg}[33,34]$. Even with its relatively low toxicity, this compound still caused poisonings and lethal effects [35]. Table 3 displays proposed levels of acute oral toxicity of metaldehyde compound $[33,34]$.

Previous research has reported that oral mammalian toxicity is as high as $630 \mathrm{mg} / \mathrm{kg}$ to rats $[36,37]$. Ranges recorded for dogs are between $250 \mathrm{mg} / \mathrm{kg}$ and $1000 \mathrm{mg} / \mathrm{kg}$. Death has occurred among dogs due to accidental ingestion of bait pellets. Another study reported the death of birds on metaldehyde [38]. However, no accurate level of oral $\mathrm{LD}_{50}$ has been reported. According to [32], birds that ingested metaldehyde experienced several reactions including complicated breathing, tremors, excitability, muscle spasms and diarrhoea. A minimum lethal dose of metaldehyde is below $1000 \mathrm{mg} / \mathrm{kg}$ for chickens and ducks [39]. 


\section{Journal of Civil Engineering, Science and Technology}

Volume 8, Issue 2, September 2017

Table 3: Acute oral toxicity of metaldehyde for different animals species

\begin{tabular}{ll}
\hline Animals & Dose $(\mathrm{mg} / \mathrm{kg})$ \\
\hline Rat & $227-690$ \\
Rabbit & $290-1250$ \\
Mouse & 200 \\
Guinea pig & $175-700$ \\
Dog & $100-1000$ \\
\hline
\end{tabular}

In another case, metaldehyde treatment in paddy rice was found to be relatively non-toxic to two freshwater fishes (carps and tilapia) [15]. This was due to the resistance features of these two species toward pesticides, especially in low concentrations. For another two species of fish (rainbow trout and bluegill), $\mathrm{LD}_{50}$ values of not more than $100 \mu \mathrm{g} / \mathrm{L}$ have been recorded [40]. No mortality was observed in several freshwater fishes and shellfish including juvenile milkfish (Chanos chanos), shrimp (Penaues monodon and Metapenaues ensis), tilapia (Tilapia mossambicus), small crustaceans (Artemia salina) and crab (Scylla serrata), when exposed to metaldehyde in test basins with various rates of application [41].

Effects of metaldehyde concentration on the Pacific oyster (Crassostrea gigas) have been studied [30]. Cell mortality of Pacific oyster was drastically higher in the presence of metaldehyde $(10.87 \%)$. The mortality rate increased to $11.23 \%$ after three days on the same research sample. Earthworm however recorded the opposite extreme result, showing tolerance with a high concentration of metaldehyde. This was proven due to high exposure of $\mathrm{LD}_{50}$ (oral) as much as $10,000 \mathrm{mg} / \mathrm{kg}$ [37]. Not even a single earthworm died from the experiment. In the same study, metaldehyde had no negative effects on earthworm activity and growth rate.

\subsection{CONCLUSION}

Excessive use of metaldehyde in agriculture activities has led to persistent residues in ecosystems. This molluscicide has contaminated water sources which may be used as drinking water. It has bioaccumulated in fishes and other aquatic biotas. Consumption of contaminated fishes and other aquatic organisms by humans and animals is one of the issues concerned. Thus, understanding the toxicity levels of metaldehyde may assist us in continuously monitoring the existence of this compound in our environment.

\section{ACKNOWLEDGMENT}

The authors would like to express thanks to Government of Malaysia, Ministry of Higher Education Malaysia and Universiti Malaysia Perlis for the Fundamental Research Grant Scheme (FRGS) No. 9003-00386 and the MyBrain15 (MyPhD) Scholarship.

\section{REFERENCES}

[1] PAN UK (Pesticides Action Network United Kingdom). (2001). Metaldehyde. Retrieved from http://www.pan-uk.org/pestnews/Actives/Metaldeh.htm

[2] EFSA. (2010). Conclusion on the peer review of the pesticide risk assessment of the active substance metaldehyde. EFSA Journal, 8(10): 1-77.

[3] Kay, P., \& Grayson, R. (2014). Using water industry data to assess the metaldehyde pollution problem. Water and Environment Journal, 28(3): 410-417. 


\section{Journal of Civil Engineering, Science and Technology}

Volume 8, Issue 2, September 2017

[4] Brice, K. N. D., Fai, P. A. B., Norbert, N. T., \& Mbida, M. (2017). Environmental and human health assessment in relation to pesticide use by local farmers and the Cameroon Development Corporation (CDC), Fako Division, South-West Cameroon. European Scientific Journal, 13(21): 455-473.

[5] Lu, Q., Whitehead, P. G., Bussi, G., Futter, M. N., \& Nizzetto, L. (2017). Modelling metaldehyde in catchments: A River Thames case-study. Environmental Science: Processes \{\&\} Impacts, 19(4): 586595.

[6] Behrooz, R. D., Esmaili-Sari, A., Ghasempouri, S. M., Bahramifar, N., \& Covaci, A. (2009). Organochlorine pesticide and polychlorinated biphenyl residues in feathers of birds from different trophic levels of South-West Iran. Environment International, 35(2): 285-290.

[7] Yahia, D., \& Elsharkawy, E. E. (2014). Multi pesticide and PCB residues in Nile tilapia and catfish in Assiut city, Egypt. Science of the Total Environment, 466: 306-314.

[8] Schreinemachers, P., \& Tipraqsa, P. (2012). Agricultural pesticides and land use intensification in high, middle and low income countries. Food Policy, 37(6): 616-626.

[9] PAN UK (Pesticides Action Network United Kingdom). (2013). Pesticides database-pesticides registration status. Retrieved from http://www.pesticideinfo.org/List_Chemicals.jsp?

[10] Lin, W. X. (2002). The compilation of residue limits standards for pesticides and veterinary drugs in foodstuffs in the world. Dalian: Dalian Maritime University Press.

[11] Khan, S. A., Suleman, M., \& Asad, M. (2017). Assessment of pollution load in marble waste water in Khairabad, District Nowshera, Khyber Pukhtunkhwa, Pakistan. Int. J. Economic and Environmental Geology, Vol, 8(2): 35-39.

[12] R. S. Wilder, \& Park, A. (1947). Preparation of metaldehyde. Retrieved from https://toxnet.nlm.nih.gov/cgi-bin/sis/search/a?dbs+hsdb:@term+@DOC NO+1735

[13] Viswas, A., \& Tewari, K. (2009). A textbook of organic chemistry, $3^{\text {rd }}$ edition. Vikas Publishing House Pvt. Ltd.

[14] INCHEM (International Programme on Chemical Safety). (1996). Pesticide information profile Metaldehyde. Retrieved from http://www.toxipedia.org/display/ toxipedia/Metaldehyde

[15] Calumpang, S. M. F., Medina, M. J. B., Tejada, A. W., \& Medina, J. R. (1995). Environmental impact of two molluscicides: Niclosamide and metaldehyde in a rice paddy ecosystem. Bulletin of Environmental Contamination and Toxicology, 55(4): 494-501.

[16] Thanawong, K., Perret, S. R., \& Basset-Mens, C. (2014). Eco-efficiency of paddy rice production in Northeastern Thailand: A comparison of rain-fed and irrigated cropping systems. Journal of Cleaner Production, 73: 204-217.

[17] Coloso, R. M., Borlongan, I. G., \& Blum, R. A. (1998). Use of metaldehyde as a molluscicide in semicommercial and commercial milkfish ponds. Crop Protection, 17(8): 669-674.

[18] Brienza, M., \& Chiron, S. (2017). Enantioselective reductive transformation of climbazole: A concept towards quantitative biodegradation assessment in anaerobic biological treatment processes. Water Research, 116: 203-210.

[19] Zhang, H., Wang, C., Lu, H., Guan, W., \& Ma, Y. (2011). Residues and dissipation dynamics of molluscicide metaldehyde in cabbage and soil. Ecotoxicology and Environmental Safety, 74(6): 16531658.

[20] PMRA (Health Canada's Pest Management Regulatory Agency). (2016). Proposed maximum residue limit PMRL2016-23, Metaldehyde. Retrieved from http://www.hc-sc.gc.ca/cps-spc/pest/ part/consultations/_pmrl2016-23/pmrl2016-23-eng.php

[21] US GPO (U.S Government Publishing Office). (2016). Metaldehyde; tolerances for residues. Retrieved from https:/www.ecfr.gov/cgi-bin/text-idx?SID=bd54bea41ce88 d7a43e20d0a774cb629\&mc $=$ true \&node $=$ se40.26.180_15 23\&rgn=div8

[22] UK EA (United Kingdom Environmental Agency). (2009). The determination of metaldehyde in waters using chromatography with mass spectrometric detection. Retrieved from http://www.environmentagency.gov.uk/static/documents/Research/Metaldehyde-226b.pdf

[23] Mathiesen, K. (2013). Slug poison found in one in eight of England's drinking water sources. The Guardian. Retrieved from https:/www.theguardian.com/environment/ 2013/jul/10/slug-poisondrinking-water-metaldehyde

[24] UK EA (United Kingdom Environmental Agency). (2011). Environment agency position on metaldehyde, v.2. Retrieved from http://publications.environment-agency.gov.uk/PDF/GEHO0811 BTVG-E-E.pdf

[25] Hillocks, R. J. (2012). Farming with fewer pesticides: EU pesticide review and resulting challenges for UK agriculture. Crop Protection, 31(1): 85-93. 


\section{Journal of Civil Engineering, Science and Technology}

Volume 8, Issue 2, September 2017

[26] CEM (Council of the European Communities). (1998). Directive of the European Parliament and of the Council on the Quality of Water Intended for Human Consumption (98/83/EC). Retrieved from http://eur-lex.europa.eu/legal-content/EN/TXT/?uri=CELEX\%3A31998L0083

[27] Bristol Water. (2012). Briefing on metaldehyde. Retrieved from http://www.bristolwater.co. uk/news/general/

[28] Lazartigues, A., Banas, D., Feidt, C., Brun-Bellut, J., \& Thomas, M. (2012). Pesticide pressure and fish farming in barrage pond in Northeastern France Part I: Site characterization and water quality. Environmental Science and Pollution Research, 19(7): 2802-2812.

[29] ALS Environmental. (2014). Determination of pesticides in water. Retrieved from http:/www.alsenvironmental.co.uk/website/media-uk/pdf/datasheets/drinking-water/ als_dw_metal dehyde_v1_2014.pdf

[30] Moreau, P., Burgeot, T., \& Renault, T. (2015). In vivo effects of metaldehyde on pacific oyster, crassostrea gigas: Comparing hemocyte parameters in two oyster families. Environmental Science and Pollution Research, 22(11): 8003-8009.

[31] Horgan, F. G., Felix, M. I., Portalanza, D. E., Sánchez, L., Rios, W. M. M., Farah, S. E., ... Espin, E. B. (2014). Responses by farmers to the apple snail invasion of Ecuador's rice fields and attitudes toward predatory snail kites. Crop Protection, 62: 135-143.

[32] Gupta, R. C. (2012). Metaldehyde. In R. C. Gupta (Ed.), Veterinary toxicology: Basic and clinical principles (pp. 518-521). Academic Press.

[33] US NLM (United States National Library of Medicine). (1995). Hazardous substances databank: Metaldehyde. Retrieved from https://toxnet.nlm.nih.gov/cgi-bin/sis/search2/f?./temp/ YeAKr3:1

[34] Hayes, W. J., \& Laws, E. R. (1991). Handbook of pesticide toxicology. Academic Press.

[35] Chu, W., Rao, Y., \& Hui, W. Y. (2009). Removal of simazine in a UV/TiO2 heterogeneous system. Journal of Agricultural and Food Chemistry, 57(15): 6944-6949.

[36] Berg, H. (2001). Pesticide use in rice and rice-fish farms in the Mekong Delta, Vietnam. Crop Protection, 20(10): 897-905.

[37] Edwards, C. A., Arancon, N. Q., Vasko-Bennett, M., Little, B., \& Askar, A. (2009). The relative toxicity of metaldehyde and iron phosphate-based molluscicides to earthworms. Crop Protection, 28(4): 289-294.

[38] Kidd, H., \& James, D. R. (1991). The agrochemicals handbook, third edition. Cambridge: Royal Society of Chemistry Information Services.

[39] WHO (World Health Organization). (1996). WHO/FAO data sheet on pesticides. no. 93, Metaldehyde. Retrieved from http://apps.who.int/iris/bitstream/10665/63291/1/WHO_PCS_DS_96.93.pdf

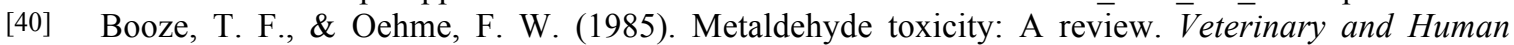
Toxicology, 27(1): 11.

[41] Borlongan, I. G., Coloso, R. M., \& Blum, R. A. (1996). Use of metaldehyde as molluscicide in milkfish ponds. In slug and snail pests in agriculture. Proceedings of a Symposium organized by The British Crop Protection Council in conjunction with The Association of Applied Biologists and The Malacological Society of London, held at the University of Kent Canterbury, (pp. 205-212). British Crop Protection Council. 